\title{
Flow-of-Funds Analysis of the Sumitomo Zaibatsu
}

\author{
By Shoichi Asajima \\ Senshu University \\ Translated by Michael Smitka
}

\section{Topic and Approach}

There have been many studies of the Japanese Zaibatsu, but relatively little work has been done on Sumitomo, and there are no studies which try to look at this zaibatsu in its entirety. This paper 1 ) is a step toward filling in this gap. The use of flow-of-funds analysis is also a new technique in the analysis of zaibatsu.

This paper will look at the supply of and demand for funds of the principal members of the Sumitomo zaibatsu, and the relations of these firms with the "parent" (holding) company and with financial institutions of the zaibatsu. The growth of the zaibatsu had to be financed in some fashion, and tracing out the source of the requisite funds is thus one useful way to gain a better understanding of the structure of this multienterprise organization. In sum this paper will try to look at which parts of the zaibatsu earned profits, and how these funds were controlled and invested, as well as how and where funds from outside the zaibatsu were used.

The first generation of studies of the zaibatsu tended to focus on the analysis of the financial statements of individual firms, in part due to data limitations. In these the principal balance sheet and profit/loss statement items are set forth, and an attempt made to explain the changes therein. While such studies are necessary, it is also important to try to trace the flow of funds of individual firm, and of the zaibatsu as a whole. One summary feature of a firm's activities is its financial balance, and an analysis of this is a natural next step to take in the study of the zaibatsu.

Firms as a rule did not make public data on their financial flows, and so it is necessary to try to deduce them from annual reports. This will be done by contrasting year-end balance sheets, looking at the net changes in principal accounting categories for the year, and summing these changes to determine the overall financial balance. This balance, herein called the operating balance, is comprised of fixed investment, investment in securities (including those of subsidiaries), and income and expenditures which reflect the outcome of day-to-day operations. When the operating balance is in deficit, expenditures exceed income, and this gap must in 
some way be financed. Normal methods of doing this included increasing capital, calls on unpaid shares, borrowing, discounting bills, issuing promissory notes, floating bonds, and drawing down current and other deposits. When the operating balance is in surplus the opposite of the above must take place, e.g. loans are repaid, bills and notes settled, bonds redeemed, and deposits increased. These individual changes, the sum of which is the operating balance, are here called the financial flow. In practice, it was found that within the Sumitomo zaibatsu the major item affecting the operating balance was investment in fixed capital, and this investment is then ultimately refected by changes in the financial flow.

In this paper it is not possible to examine separately each member of the Sumitomo zaibatsu. Firms herein will therefore be grouped into five categories: the parent firm, the financial sector, the manufacturing sector, the mining sector, and the service sector. In addition, only companies controlled directly or indirectly by the parent company will be considered. ${ }^{2}$ ) Of "affiliated" companies, in which Sumitomo had a minority stake, only two (Nippon Sheet Glass Co. and Nippon Electric Co.) of any significance were excluded, so this is not a serious restriction. Further, the most important sectors for analyzing fund flows proved to be the manufacturing, service, and mining sectors and the parent firm, while the financial sector had a passive role as an acceptor of deposits or provider of loans. This analysis will therefore concentrate on the first three sectors, and the coordinating role of the parent firm.

Finally, the period covered by this analysis will be from the time of the establishment of Sumitomo Göshi Kaisha, a limited partnership, to serve as the holding company of the zaibatsu in February 1921, through 1943, after which the impact of World War II makes further analysis impossible. This period will be subdivided into two parts, with the breakpoint being the reorganization of the parent company into Sumitomo Honsha Co., a joint-stock company, in March 1937. For convenience, the period from 1921 to 1936 will be referred to as the "Gōshi" period, and that from 1937 through 1943 as the "Honsha" period. These two periods were the most important ones for the growth and diversification of the Sumitomo zaibatsu, so that the exclusion of the period prior to 1921 and the period from 1944 until the breakup of the Zaibatsu in 1946 by the U.S. Occupation (for which data is unavailable) is not critical for an understanding of the structure of the zaibatsu. 


\section{Fixed Investment and the Operating Balance}

\section{a) Changes in Fixed Investment}

Changes in the level of fixed investment of individual zaibatsu members has been examined in another paper. ${ }^{3)}$ A number of the points made therein are given here for background, as investment dominated the operating balance of the zaibatsu members, which was in turn reflected in their own and the overall zaibatsu flow of funds.

The zaibatsu expanded rapidly after the establishment of Sumitomo Gōshi Kaisha, and this expansion was based on high levels of fixed investment. This was particularly true from 1924 on, when the following five projects stood out: (1) the construction of a headquarters building for the zaibatsu by Sumitomo Building Co., (2) the purchase from Osaka North Harbour Co. of land for the relocation and/or expansion of Sumitomo manufacturing sector, (3) the expansion of Sumitomo Warehouse Co.'s facilities, (4) the transfer of a power plant from Besshi Mining Office to Tosa Yoshinogawa Hydroelectric Power Co., and (5) land purchases by Sumitomo Gōshi. By 1929, when the reorganization and expansion of the main non-manufacturing sector firms had slowed, three other projects stood out: (1) the construction by Sumitomo Fertilizer Works of a nitrogen plant, (2) the reorganization of the mining sector, including the establishment of Sumitomo Colliery Co. and the spinning off of Sumitomo Besshi Mine Co. from Sumitomo Gōshi, and (3) the construction of a power plant by Tosa Yoshinogawa Hydroelectric. Due to a recession investment declined during 1930-1932, when the only large project was the expansion of Sumitomo Fertilizer's facilities.

From 1933 on however there was a boom in the manufacturing sector in Japan, and for Sumitomo this was reflected in the spinning off from Sumitomo Besshi Mine of Sumitomo Machinery Co., the establishment of Sumitomo Aluminium Reduction Co. and Manchuria Sumitomo Steel Tube Co., the construction of new electric power plants, and the expansion of facilities in existing manufacturing companies. In contrast there was little new investment in the mining sector, and if anything (due to depreciation) there was a decline in the book value of fixed assets. The mining sector continued to play a minor role until the onset of wartime economic controls. With the start of the war with China in 1937 there was more emphasis on the expansion of existing companies than in the establishment of new ventures. Sumitomo Metal Industries formed by the merger of Sumitomo Steel Works and Sumitomo Steel Tube \& Copper Works - expanded tremendously under the impact of military procurement, requiring huge amounts of funds for investment; 
it became the largest firm in the zaibatsu, surpassing Sumitomo Bank in size. The only break in the growth of the zaibatsu as a whole in the period after 1933 came in 1940, under the impact of production bottlenecks and the weight of investment being undertaken to meet anticipated demand.

The war stimulated the expansion of not only Sumitomo Metal Industries but also the rest of the manufacturing sector and the electric power companies. This included the expansion of Nippon Electric Co. and, in the face of prospective wartime demand, significant investment for increasing output, including the opening of new mines, in Sumitomo Mining Co. (formed by the merger of Sumitomo Besshi Mining and Sumitomo Colliery in 1937). In contrast the service sector did not expand much, and with the gradual spinning off of its operating divisions as separate companies the parent firm itself had little demand for investment funds; it came to function more as just a holding company. In turn as the war progressed the major manufacturing and mining firms increased their own investments in subsidiaries and "grandchild" companies, and Sumitomo Metal Industries, Sumitomo Chemical and Sumitomo Mining by the end of the period were themselves significant holding companies.

\section{b) The Operating Balance}

The investment activities traced out above gave rise to a demand for funds, but of course this is not necessarily reflected in the operating balance, in which the flows arising from investment are conflated with the autonomous flows associated with normal business activities and changes in securities investments. The focus here is on the operating balance itself, which is given in Table 1. The following looks at this balance, mainly at the sectoral level.

During the 1920's there was some investment in the manufacturing sector, but this was covered by profits and depreciation, and hence the operating balance remained in surplus. The service sector, on the other hand, could not cover its own demand for funds for building and warehouse construction, and its operating balance was therefore in deficit. These two balances largely cancelled out, so the combined operating balance for the three principal sectors showed only a small deficit.

In the late 1920's, reflecting the effort to strengthen the zaibatsu through the expansion of the manufacturing sector described above, the combined operating balance of the three sectors showed a large deficit. In $1928-1930$ this reached as high as $¥ 7-8$ million yen, with each of the three sectors showing a sizable net demand for funds. During 1931-1933, the ongoing expansion of Sumitomo Fertilizer and other manufacturing firms gave rise to some demand for funds, but the operating balance 


Manufacturing Sector Total
Sumitomo Copper Works
Sumitomo Steel Works
Sumitomo Electric Wire \& Cable Works
Sumitomo Fertilizer Works
Non-Manufacturing Sector Total
Sumitomo Warehouse
Osaka North Harbour
Tosa Yoshinogawa Hydro Electric Power
Sumitomo Building

Mining Sector Total Sumitomo Besshi Mine Sumitomo Kyushu Colliery Sumitomo Ban Colliery

Three Sectors, Total

Parent Firm (A)

Parent Firm (B)
- indicates deficit unit 1,000 yen

( ) not included in totals

$\begin{array}{rrrrrrrr}1921 & 1922 & 1923 & 1924 & 1925 & 1926 & 1927 & 1928 \\ 1,013 & -1,884 & 2,045 & 2,040 & 3,157 & 227 & 1,223 & -6,489 \\ (4,229) & (1,247) & (2,220) & (1,766) & (1,155) & (1,133) & 39 & -5,330 \\ 742 & -671 & 1,674 & 497 & 438 & 700 & 908 & 0 \\ 271 & -1,213 & 371 & 1,543 & 2,719 & -401 & 850 & -1,074 \\ (606) & (-385) & (634) & (91) & (552) & -72 & -574 & -85 \\ & & & & & & & \\ (?) & (?) & (?) & -1,227 & 598 & -699 & -352 & -62 \\ & & & & & & & 751 \\ & & -1,751 & -1,423 & -2,821 & -462 & 256 & -290 \\ & & & & & & -3,154 & -1,337 \\ (?) & (?) & (?) & (?) & (?) & (?) & (?) & -1,389 \\ (?) & (?) & (?) & (?) & (?) & (?) & (?) & \\ & & & & & & -92 & 52 \\ 1,013 & -1,884 & 294 & -610 & 934 & -934 & -2,119 & -7,330 \\ & & 2,109 & -378 & -673 & -5,383 & -4,547 & -3,240\end{array}$




\begin{tabular}{|c|c|c|c|c|c|c|c|c|}
\hline & 1929 & 1930 & 1931 & 1932 & 1933 & 1934 & 1935 & 1936 \\
\hline Manufacturing Sector Total & 1,929 & $-4,419$ & $-1,272$ & 177 & -843 & $-18,212$ & $-18,346$ & 6,704 \\
\hline Sumitomo Steel Tube \& Copper Works & 1,239 & -304 & 1,834 & 2,111 & 1,938 & $-10,765$ & & \\
\hline Sumitomo Steel Works & 701 & 590 & $-1,205$ & -352 & $-2,736$ & $-4,877$ & $-1,824$ & -909 \\
\hline Sumitomo Electric Wire \& Cable Works & 766 & 1,110 & $-1,075$ & -726 & 763 & -937 & 702 & 2,494 \\
\hline Sumitomo Fertilizer Works & -777 & $-5,815$ & -826 & -856 & -808 & $-1,633$ & $-5,379$ & $-5,533$ \\
\hline Sumitomo Machinery & & & & & & & -684 & -367 \\
\hline Sumitomo Aluminium Reduction & & & & & & & $-2,143$ & $-1,288$ \\
\hline Manchuria Sumitomo Steel Tube & & & & & & & $-3,018$ & $-1,101$ \\
\hline Non-Manufacturing Sector Total & $-3,944$ & $-3,289$ & 254 & 859 & 1,376 & -298 & $-1,235$ & $-1,204$ \\
\hline Sumitomo Warehouse & $-1,376$ & 92 & -274 & 378 & 490 & -51 & 827 & 837 \\
\hline Osaka North Harbour & 16 & -436 & 112 & 225 & 939 & 187 & 35 & 229 \\
\hline Tosa Yoshinogawa Hydro Electric Power & $-1,658$ & $-1,812$ & 181 & 47 & -201 & -483 & $-2,356$ & $-2,377$ \\
\hline Sumitomo Building & -926 & $-1,133$ & 235 & 209 & 148 & 49 & 259 & 107 \\
\hline Mining Sector Total & $-6,683$ & $-1,223$ & -68 & 1,518 & 3,103 & 1,547 & 1,519 & 175 \\
\hline Sumitomo Besshi Mine & 9 & -69 & -9 & 1,134 & 2,886 & 852 & 1,266 & -371 \\
\hline $\begin{array}{l}\text { Sumitomo Kyushu Colliery } \\
\text { Sumitomo Ban Colliery }\end{array}$ & $\begin{array}{l}-1,312 \\
-5,380\end{array}$ & $-1,154$ & -59 & 384 & 217 & 696 & 253 & 546 \\
\hline Three Sectors, Total & $-8,698$ & $-8,931$ & $-1,086$ & 2,554 & 3,636 & $-16,963$ & $-18,062$ & $-7,733$ \\
\hline Parent Firm (A) & 336 & $-1,950$ & $-6,749$ & $-5,693$ & $-7,939$ & $?$ & 32,579 & $-2,738$ \\
\hline Parent Firm (B) & & & & & & & 33,450 & $-1,600$ \\
\hline
\end{tabular}




\begin{tabular}{|c|c|c|c|c|c|c|c|}
\hline & 1937 & 1938 & 1939 & 1940 & 1941 & 1942 & 1943 \\
\hline Manufacturing Sector Total & $-52,381$ & $-42,439$ & $-91,787$ & $-112,983$ & $-160,134$ & $-295,770$ & $-381,910$ \\
\hline Sumitomo Metal Industries & $-21,928$ & $-15,452$ & $-42,251$ & $-53,497$ & $-106,773$ & $-238,370$ & $-234,340$ \\
\hline Sumitomo Electric Wire \& Cable Works & $-22,208$ & $-5,306$ & $-7,975$ & $-21,447$ & $-8,169$ & $-12,040$ & $-21,460$ \\
\hline Sumitomo Fertilizer Works & $-3,009$ & $-9,986$ & $-11,027$ & $-18,328$ & $-14,895$ & $-34,630$ & $-39,820$ \\
\hline Sumitomo Machinery & $-4,554$ & $-1,867$ & $-2,340$ & -613 & $-11,096$ & $-4,310$ & $-16,080$ \\
\hline Sumitomo Aluminium Reduction & -224 & -806 & $-9,415$ & $-9,881$ & $-8,103$ & $-1,070$ & $-5,610$ \\
\hline $\begin{array}{l}\text { Manchuria Sumitomo Steel Tube } \\
\text { Nippon Electric }\end{array}$ & -458 & $-9,022$ & $-18,779$ & $-9,217$ & $-11,098$ & $-5,350$ & $\begin{array}{r}-4,410 \\
-60,190\end{array}$ \\
\hline Non-Manufacturing Sector Total & $-3,014$ & 1,556 & -974 & $-10,845$ & $-7,145$ & 6,970 & $-5,880$ \\
\hline Sumitomo Warehouse & -80 & 1,665 & 3,623 & 1,652 & 2,290 & 990 & -720 \\
\hline Osaka North Harbour & 2,187 & 1,755 & 2,382 & $-2,970$ & -741 & -550 & $-1,040$ \\
\hline Shikoku Central Electric Power & $-4,758$ & $-2,222$ & $-7,280$ & $-9,943$ & $-8,954$ & 6,210 & $-4,460$ \\
\hline Sumitomo Building & -363 & 358 & 301 & 416 & 260 & 320 & 340 \\
\hline Mining Sector Total & $-1,900$ & 1,760 & $-16,110$ & $-28,060$ & $-20,730$ & $-12,600$ & $-4,040$ \\
\hline Sumitomo Mining & $-1,900$ & 1,760 & $-16,110$ & $-28,060$ & $-20,730$ & $-12,600$ & $-4,040$ \\
\hline Three Sectors, Total & $-57,295$ & $-39,123$ & $-108,871$ & $-151,888$ & $-188,009$ & $-301,400$ & $-391,830$ \\
\hline Parent Firm (A) & $-21,980$ & $-43,030$ & $-23,140$ & $-17,568$ & $-14,181$ & $-40,940$ & $-20,190$ \\
\hline Parent Firm (B) & $-20,740$ & $-44,670$ & $-28,540$ & $-30,150$ & $-21,050$ & $-30,800$ & $-7,910$ \\
\hline
\end{tabular}

Note: See Rider (4) etc. for sources. Blank where firm not yet established, ( ) indicates operated as division of parent firm, mergers as indicated. Parent $(A)$ is for holding operations alone, Parent $(B)$ includes this as well as mining, retail and health care operations. All numbers rounded. 
overall was in surplus. The Sumitomo zaibatsu was affected by the Depression, but its impact showed up in the operating balance only after a lag of one or two years. Thus in 1931, although no new projects were undertaken, investment begun in previous years continued to affect the balance, while the economic recovery and renewed investment in 1933 did not show up until subsequent years.

From 1934 on the operating balance of the zaibatsu as a whole showed a continuing and large deficit. Initially this stemmed from manufacturing investment, and from the expansion of Shikoku Central Electric Power Co. (Tosa Yoshinogawa renamed), which served the manufacturing sector. The balance of the mining sector, however, continued in surplus. From 1937 on, under the impact of military procurement, the above pattern was strengthened, and the combined deficit of the three sectors became an order of magnitude greater. Even the operating balance of the mining sector went into a deficit, and as the war expanded the deficit of the zaibatsu as a whole continued to increase rapidly. The largest single deficit was that of the manufacturing sector, which was in turn dominated by that of Sumitomo Metal Industries. This one firm alone accounted for $30-80 \%$ of the deficit of the zaibatsu as a whole, with the remainder stemming mainly from the other manufacturing firms, the electric power companies and Sumitomo Mining.

Finally, the operating balance of the parent company during the Gōshi period (the Parent (A) in Table 1) varied substantially, and was often in deficit. Operating divisions of the parent company are not included in this total; the balance thus reflects only the holding company side of the parent company, the Sumitomo Gōshi, and includes investment in securities, loans to and deposits by member firms and its own operating divisions, and dividends paid to its owners, the Sumitomo family. Other investments by the parent firm would also be included, but during this period there appear to have been only some minor land purchases. The large surplus in 1935 stemmed from the sale of a portion of its share in the stock of Sumitomo Metal Industries. In the Honsha period, however, the operating balance was always in deficit, and as with the deficits of the three main sectors, this figure was a multiple of its previous levels. The principal factor here was the increase in capital paid into zaibatsu firms, and for 1938 the payment of tax obligations which arose from the liquidation of Sumitomo Gōshi. 


\section{The Financial Flow}

\section{A(1). The Three Main Sectors in the Gōshi Period (1921-1936)}

The combined operating balance for the three sectors of the Sumitomo zaibatsu can be found in the leftmost column at the top of Table 2. The financing of this operating balance is broken down into five categories: increases in paid-up capital, decreases in deposits, increases in borrowings, increases in notes issued, and bond flotations. Increases in capitalization and of paid-up capital (hereafter "paid-up capital") took place in most years, with a total for the period of $¥ 62.45$ million. While the fund sources which were used to cover the operating balance varied from year to year, over the entire period the increase in paid-up capital exceeded the operating balance deficit. Thus while the deficit in the operating balance may have been financed in the short run by decreases in deposits, borrowings and the like, in the end these were all covered by changes in paid-up capital. In fact deposits increased in most years, and showed a net increase of $¥ 12.67$ million by the end of the period, though of course the pattern at the firm level was more varied. Several firms - Sumitomo Steel Works, Sumitomo Electric Wire, Osaka North Harbour, and Sumitomo Steel Tube - held large deposits, most of which were placed with the parent firm, adjusting the exact level in line with business needs. Some of the deposits of these four firms, along with all the deposits with Sumitomo Gōshi of other zaibatsu members, appear to in turn have been held as working funds with Sumitomo Bank. In any event, these deposits, which appear to be the surplus funds of the zaibatsu members, were used by Sumitomo Gōshi for its own needs and for loans to other zaibatsu members. Firms in the zaibatsu first resorted to loans in 1924, and this development appears to be related to the spinning off of operating divisions of the parent firm into separate companies. Until that time the operating balance of those divisions had been financed internally. When loans appeared, they were limited to a relatively few firms. Sumitomo Warehouse and Sumitomo Building (and, for a brief period, Sumitomo Steel Tube and Sumitomo Ban Colliery) borrowed from the parent firm, while three firms borrowed from Sumitomo Bank or Sumitomo Trust (Sumitomo Fertilizer, Sumitomo Building, and Tosa Yoshinogawa Hydroelectric); only one firm (Osaka North Harbour) borrowed from outside the zaibatsu. The issuing of notes was also quite limited, being used only by Sumitomo Fertilizer and the various mining companies, who for some reason preferred this to bank loans. There is no evidence to indicate who held these notes, but it is clear that they were not bills issued to settle specific transactions. By the end of the 


\section{Table 2 Summary of Financial Income and Expenditures}

1. The Sumitomo Goshi Period

\begin{tabular}{|c|c|c|c|c|c|c|}
\hline & $\begin{array}{l}\text { Business income and } \\
\text { expenditures/ } \\
* \text { (deficit) }\end{array}$ & $\begin{array}{l}\text { Paid-up } \\
\text { capital }\end{array}$ & $\begin{array}{l}\text { Other deposit with- } \\
\text { drawals/* (savings } \\
\text { increase) }\end{array}$ & $\begin{array}{l}\text { Methods of increase } \\
\text { borrowing/ } \\
\text { * (refunding) }\end{array}$ & $\begin{array}{c}\text { Handling issue notes } \\
\text { payable/* (account } \\
\text { settled) }\end{array}$ & $\begin{array}{l}\text { Issue bonds/ } \\
* \text { (bond } \\
\text { redemption) }\end{array}$ \\
\hline 1922 & * 1884 & 1250 & 645 & & & \\
\hline 1923 & 294 & 2275 & * 2565 & & & \\
\hline 1924 & $* 610$ & 975 & * 1532 & 597 & & 572 \\
\hline 1925 & 937 & 3250 & * 3594 & * 591 & & \\
\hline 1926 & * 938 & & 238 & 700 & & \\
\hline 1927 & * 2118 & 2750 & * 1567 & 699 & 235 & \\
\hline 1928 & * 7330 & 3000 & * 509 & * 272 & 5106 & \\
\hline 1929 & * 8698 & 4000 & * 552 & 4691 & 570 & \\
\hline 1930 & * 8933 & 5000 & * 1057 & 1910 & 3070 & \\
\hline 1931 & * 1086 & & 1989 & 1877 & * 2782 & \\
\hline 1932 & 2554 & & * 1389 & * 690 & * 467 & \\
\hline 1933 & 3636 & 4200 & * 1421 & * 833 & * 5013 & ${ }^{*} 572$ \\
\hline 1934 & * 16963 & 23000 & 493 & * 3555 & * 2975 & \\
\hline 1935 & $(* 10238)$ & $(6500)$ & $(* 143)$ & $(2680)$ & $(1200)$ & \\
\hline 1936 & * 7733 & 6250 & * 1707 & 1434 & 1757 & \\
\hline Total & * 59110 & 62450 & * 12671 & 8647 & 701 & 0 \\
\hline
\end{tabular}


2. The Sumitomo Honsha Period

\begin{tabular}{|c|c|c|c|c|c|c|}
\hline & & & & & lunit: 1 & 000 yen) \\
\hline & Business income and & Paid-up capital & & Borrowing & & Bonds \\
\hline & (* deficit) & & Honsha & Bank/Trust Co. & Other & \\
\hline 1937 & * 53,180 & 45,630 & 3,850 & 3,690 & & \\
\hline 1938 & * 34,050 & 32,240 & $* 10,250$ & 12,060 & & \\
\hline 1939 & * 100,070 & 57,100 & * 9,430 & 52,400 & & \\
\hline 1940 & * 150,230 & 55,000 & 19,460 & 31,910 & 13,860 & 30,000 \\
\hline 1941 & * 187,310 & 29,000 & 750 & 73,160 & 9,600 & 74,800 \\
\hline 1942 & $* 301,400$ & 71,500 & 500 & 127,950 & 22,450 & 79,000 \\
\hline 1943 & * 391,830 & 65,000 & 600 & 88,290 & 147,250 & 90,700 \\
\hline Sub-total & * 1,218,070 & 355,470 & 5,480 & 389,460 & 193,160 & 274,500 \\
\hline Component ratio & $(100)$ & $(29.2)$ & $(0.4)$ & $(32.0)$ & $(15.9)$ & $(22.5)$ \\
\hline
\end{tabular}

Notes: See Rider (5) etc. for sources. ( ) for 1935 indicate estimates. All numbers rounded. 
period most outstanding notes had been paid off. There was only one issuance of corporate bonds, a $¥ 5.7$ million flotation by Sumitomo Warehouse in 1924, and there is no evidence as to why this was done.

It needs to be kept in mind that Table 2 reflects sectoral aggregates, and that the pattern at the firm level was often quite different. In general there were two broad patterns. The first was of firms which adjusted their cash balances in response to their operating balance, drawing down their deposits in deficit years and increasing them in surplus years. Representatives of this group are Sumitomo Steel, Sumitomo Electric Wire \& Cable, Osaka North Harbour, and Besshi Mines. Two other firms, which relied in part on increases in their paid-up capital - Sumitomo Machinery and Manchuria Sumitomo Metal Industries - also fit this pattern. A second pattern was of firms which used debt financing loans, notes and discounts, and bonds - and adjusted their outstanding debt balance in response to changes in their operating balances. These firms were Sumitomo Warehouse (loans and bonds); Tosa Hydroelectric, Sumitomo Aluminium and Sumitomo Ban Colliery (loans); Sumitomo Fertilizer and Sumitomo Building (loans and notes); and Sumitomo Steel Tube, Sumitomo Colliery and Sumitomo Kyushu Colliery (notes and discounts). These firms, when their operating balance was in surplus, or when their paid-up capital was increased, would reduce their debt, and if they still had funds remaining, would become depositors.

\section{A(2). The Three Main Sectors in the Honsha Period (1937-43)}

The combined operating balance for the zaibatsu from 1937 on is given in the bottom half of Table 2, and it is immediately apparent that the deficit is an order of magnitude greater than in the previous Gōshi period. There was of course a dramatic increase in investment in production facilities of the manufacturing sector, but the rapidity of the increase of the deficit is surprising. Increases in paid-up capital are substantially greater than in the Gōshi period, but such funds still covered only $29 \%$ of the accumulated operating deficit of the zaibatsu by the end of the period. The role of the parent firm in meeting the funding needs of zaibatsu members declined, and eventually it ceased to be even the primary source. As can be seen in the borrowings column for the parent firm in Table 2, it was able to receive funds on a net basis from member firms in 1938 and 1939, which it lent back out in 1940, but the amount was relatively small compared to other items. These particular fund movements can be traced to the reorganization of the parent firm, and served to provide a source for the payment of the tax liabilities which arose there from. In particular, funds from Sumitomo 
Metal Industries, Osaka North Harbour and Sumitomo Electric Industries were used to tide over the parent firm's cash flow problems at this time. To the extent that this reflects a more limited financial capability of the parent firm, then it follows that increases in paid-up capital would not be as important as the past, and that members of the zaibatsu would therefore have to rely more on loans and bonds. Indeed it is found that borrowings from Sumitomo Bank and Sumitomo Trust Co. covered 32\% of the cumulative operating balance deficit during the Honsha period, with loans from other sources accounting for a further $16 \%$, so that in contrast to the Gōshi period loans covered roughly half of the operating balance. It should be noted that the outside loans came from specialpurpose financial institutions such as the Wartime Credit Bank, and not from private financial institutions. Finally, bond issues were also widely used, accounting for the remaining $22 \%$ of the funding of the operating balance deficit.

\section{B(1). Increases in Paid-up Capital in the Gōshi Period}

The increases in paid-up capital in zaibatsu members, detailed in Table 3 , came to $¥ 135$ million during this period. About $79 \%$ of these funds were provided by the parent company, and as such increases were the primary method of financing the operating balance deficit; the role of the parent company was thus very important. It needs to be pointed out however that the capitalization of operating divisions of Sumitomo Gōshi which were spun off in this period are also included in this total. These cases included Sumitomo Warehouse, Sumitomo Copper Works (later Sumitomo Steel Tube \& Copper Works), Besshi Mine Office (later Sumitomo Besshi Mine Co.), and Wakamatsu Coal Mining Office (later Sumitomo Kyushu Colliery Co.). The initial capitalization (which corresponded to their book value as operating divisions) of these four firms alone came to $¥ 43.87$ million, and thus only about $70 \%$ of the figure for cumulative paid-up capital increases represents real flows; the rest is merely the rewriting of fixed assets as shareholdings in subsidiaries in Sumitomo Gōshi's books, and are thus not relevant for the analysis of the financial flow. The rest of the section will look at the real flows, which came to $¥ 62.4$ million. These latter shareholding investments had to be financed in some fashion, which the following will try to illuminate.

The funding source for such investments was dividends received by the parent firm. The middle column in Table 3 gives dividends paid by zaibatsu members to the parent firm. Over the period the dividends received by Gōshi came to $¥ 73.55$ million, sufficient to cover the in- 


\section{Table 3 Breakdown of Paid-up Capital}

1. The Sumitomo Goshi Period

\begin{tabular}{lrrr}
\multicolumn{4}{c}{ Payment amounts } \\
& Total & $\begin{array}{c}\text { The Goshi- } \\
\text { kaisha }\end{array}$ & Other \\
& & & \\
1922 & 1,250 & 778 & 472 \\
1923 & 17,275 & 16,087 & 1,188 \\
1924 & 975 & 487 & 488 \\
1925 & 10,050 & 4,823 & 5,227 \\
1926 & 9,000 & 9,000 & \\
1927 & 19,000 & 18,481 & 519 \\
1928 & 8,000 & 7,975 & 25 \\
1929 & 4,000 & 4,000 & \\
1930 & 5,000 & 4,959 & 41 \\
1931 & 2,500 & 1,875 & 625 \\
1932 & & & \\
1933 & 6,700 & 5,624 & 1,076 \\
1934 & 28,000 & 20,287 & 7,713 \\
1935 & 16,500 & 10,509 & 5,991 \\
1936 & 6,750 & 1,392 & 5,358 \\
Total & 135,000 & 106,277 & 28,723 \\
Component ratio & & \\
& $(100)$ & $(78.7)$ & $(21.3)$
\end{tabular}

Breakdown of the Goshikaisha payments

Investment Cash

in goods invest-

$$
\text { invest- }
$$

778

14,950$$
1,137
$$

487

4,823

9,000

14,950

4,975

43,875

3,531

3,000

4,000

4,959

1,875

5,624

20,287

10,509

1,392

62,402

ratio
Dividends paid from affiliated companies (unit: 1,000 yen)

Interest and

other dividends

\begin{tabular}{rr|r}
$\begin{array}{c}\text { Sumitomo } \\
\text { Wire \& } \\
\text { Cable Works }\end{array}$ & Other & \\
278 & 394 & 697 \\
525 & 387 & 488 \\
547 & 388 & 484 \\
547 & 387 & 492 \\
547 & 174 & 549 \\
1,372 & 688 & 622 \\
657 & 835 & 742 \\
657 & 2,836 & 831 \\
657 & 2,230 & 1,285 \\
2,005 & 402 & 1,042 \\
325 & 1,161 & 1,152 \\
1,829 & 1,983 & 1,343 \\
577 & 6,576 & $?$ \\
547 & 6,766 & 2,266 \\
584 & 4,167 & 2,398 \\
11,654 & 29,374 & 14,391 \\
& & \\
$(15.8)$ & $(40.0)$ &
\end{tabular}

Continued next page 


\section{(continued)}

2. The Sumitomo Honsha Period

(unit: 1000 yen)

\begin{tabular}{|c|c|c|c|c|c|c|}
\hline & \multicolumn{4}{|c|}{ Paid-up amounts } & \multicolumn{2}{|c|}{ Honsha dividends } \\
\hline Total & Honsha & $\begin{array}{l}\text { Main fam- } \\
\text { ily and } \\
\text { relatives }\end{array}$ & Affiliates & $\begin{array}{l}\text { Banks and } \\
\text { other exter- } \\
\text { nal sources }\end{array}$ & $\begin{array}{l}\text { From } \\
\text { affiliates }\end{array}$ & $\begin{array}{l}\text { From } \\
\text { other }\end{array}$ \\
\hline
\end{tabular}

$\begin{array}{lrrrrrrr}1937 & 49,750 & 11,490 & 3,470 & (4,120) & 30,670 & 6,019 & 1,714 \\ 1938 & 37,000 & 9,460 & 4,160 & (4,760) & 18,620 & 5,421 & 2,416 \\ 1939 & 62,500 & 18,420 & 6,490 & (5,400) & 32,190 & 6,507 & 1,939 \\ 1940 & 55,000 & 13,480 & 5,770 & 12,440 & 23,310 & 8,260 & 1,853 \\ 1941 & 29,000 & 7,040 & 9,020 & 10,290 & 2,650 & 9,143 & 2,016 \\ 1942 & 71,500 & 24,710 & 7,530 & 1,580 & 37,680 & ? & ? \\ 1943 & 65,000 & 18,130 & 4,030 & 8,270 & 34,570 & ? & ? \\ \begin{array}{l}\text { Total } 369,750 \\ \text { Component }\end{array} & 102,730 & 40,470 & 46,860 & 179,690 & ? & ? \\ \text { ratio (100) } & (27.8) & (10.9) & (12.7) & (48.6) & & \end{array}$

Notes: See Rider (4) for sources.

creases in paid-up capital in zaibatsu members, and the flow was such that this was also true in most individual years. The exceptions were in 1934 and 1935, when increases in the capital paid into the members were much greater than the dividends received.

Sumitomo Bank stands out as the source of dividends, accounting for $¥ 32.52$ million, or $44 \%$ of the total amount received by the parent firm. During the period through 1925 the only firms able to stand on their own two feet, in the sense of paying dividends, were Sumitomo Bank, Sumitomo Electric Wire \& Cable, and Sumitomo Steel. The share of the Bank among these three stood out, but the $10 \%$ dividend level of the early 1920's gradually declined to $7 \%$ by 1936 , and the share in total dividends received over a year from $70 \%$ to $20 \%$. The Bank was nevertheless a steady, and at all times the largest single, source of dividends. In addition, the entire amount represented a net receipt, as there was no increase in the paid-up capital of the Bank. Sumitomo Electric Wire also paid a dividend in all years, with the accumulated total paid over the period estimated at $¥ 11.65$ million, or about $16 \%$ of the total. It's role was surprisingly large. No other companies approached these two in importance, and to a large extent they were the funding base which the parent firm used for increasing the paid-up capital of the member firms of the zaibatsu. 
Finally, the "other" column in the "payment" in Table 3 came to $¥ 28.72$ million over the period. This number represents capital paid up in the names of the Sumitomo family and the top management of zaibatsu member firms, amounts paid up by member firms themselves, and stock sold to non-zaibatsu members through public offerings. Investment by other zaibatsu members were unusual, although the Bank and others provided much of the initial capital for the Sumitomo Trust Co., which was set up in 1925. Towards the end of the period such investment became more frequent, with such various firms taking up the capital as Sumitomo Machinery, Sumitomo Aluminium Reduction, and Manchuria Sumitomo Steel Tube upon their establishment in 1934 as subsidiaries of Sumitomo Besshi Mine and Sumitomo Steel Tube \& Copper. A number of firms also bought shares in Sumitomo Chemical and Sumitomo Metal Industries at the time of their public offerings.

\section{B(2). Increases in Paid-up Capital in the Honsha Period}

Increases in the paid-up capital of zaibatsu members during this period came to $¥ 369.75$ million, a sum several times that of the previous period. The documents which have survived permit the breakdown of this amount into that provided by the parent company, Sumitomo Honsha, by the Sumitomo family, by affiliate firms and by the bank and external interests. These numbers are given in the bottom of Table 3 .

Capital provided by the parent company totalled $¥ 102.73$ million, not much greater than in the previous period. This all represented real flows, and as the period is also shorter, it therefore represented a significant increase on an annual basis. During this period however the parent firm was able to provide only $28 \%$ of the funds for increases in the paid-up capital of zaibatsu members, and even when the Sumitomo family investments are included, the total is still under $40 \%$. The role of the parent firm had thus decreased, in spite of the increase in real investment activity. Dividends received by the parent firm cannot be detailed for the entire period, but they are known for 1937-1941. During this subperiod they came to $¥ 35.35$ million, less than the $¥ 59.89$ million in investments made. Thus in contrast to the Gōshi period, dividends received were insufficient to cover investment activity, while Sumitomo Metal Industries took over the lead from Sumitomo Bank in paying dividends, and was followed by Sumitomo Electric Wire \& Cable, Sumitomo Chemical and Sumitomo Mining.

Capital increases funded by other zaibatsu members during this period came to $¥ 46.86$ million, more than previously, but much of this amount represents book transfers which stemmed from the setting up of operating 
divisions of these firms as subsidiaries, and the initial capital for new ventures. The remaining amounts were not invested in other zaibatsu members - that is, cross-holdings did not develop among member firms but represent the increase in shareholdings by four zaibatsu members to increase the control of non-zaibatsu firms. With the onset of the war these firms - Sumitomo Metal Industries, Sumitomo Electric Wire \& Cable, Sumitomo Chemical, and Sumitomo Mining - thus began to take over some of the role as holding companies previously played by the parent firm.

Finally, the capital increases funded by financial institutions and non-zaibatsu firms or individuals came to $¥ 179.69$ million, $47 \%$ of the total. Unfortunately there is no breakdown available, but it is probable that the zaibatsu financial institutions - Sumitomo Bank, Sumitomo Trust, and Sumitomo Life Insurance - were significant. Public stock offerings during this period were also substantial in size.

\section{C(1). Changes in Deposits}

The principal financial institution in the zaibatsu was Sumitomo Bank, although there were also Sumitomo Trust Co., Sumitomo Life Insurance Co., and at a later date, Sumitomo Marine Insurance Co. Only the Bank and the Trust Company were of real importance as financial intermediaries for zaibatsu members; data is available only for the Bank. Table 4 gives the deposits of Sumitomo zaibatsu members with the parent firm and the Bank, and for comparison data on the deposits with Mitsui Bank of the parent firm, Mitsui Gōmei Kaisha, and the four largest Mitsui zaibatsu members.

According to the "Sumitomo Family Law" and later the "Sumitomo Company Operating Rules", each Sumitomo enterprise was as a rule to maintain its current accounts with the closest branch of Sumitomo Bank. This applied specifically to working funds, but it was probably customary to keep all excess funds on deposit at that branch. To the extent there were deposits with other banks, it was undoubtedly because there was no convenient branch of Sumitomo Bank, and in aggregate such amounts were probably minimal. Thus virtually all excess funds, including working funds, would show up as deposits with the Bank, the parent company, or (later) the Trust Company. During the Gōshi period, it appears that zaibatsu deposits with the Bank were on the order of $¥ 2-3$ million, with some fluctuation. But from 1926 on a number of "special deposits” were made, totalling roughly $¥ 8$ million, as reserve funds paid out of profits by the parent firm. Data on deposits by the parent firm with the Bank are incomplete, but it appears that outside 
of 1935 (when a large amount of funds were received in connection with the sale of shares of Sumitomo Metal Industries), such amounts were minor. In contrast to this, deposits with Sumitomo Bank by member firms were smaller than those with the parent firm. Excess funds were thus pooled with the parent company, rather than in the Bank, and the parent firm would then turn to the Bank for any remaining funding needs.

During the Honsha period the situation changes, with the Bank at the fore. Deposits in the Bank by member firms increased rapidly; similarly, loans by the Bank to member firms increased rapidly at this time. At the time of the reorganization of Sumitomo Gōshi into Sumitomo Honsha, the "special deposits" of the parent firm with the Bank were sliminated. These "special deposits" with the parent company began to accumulate rapidly again after 1937. Deposits by member firms with the parent firm began to decrease after 1940, while deposits of the parent firm with the Bank increased greatly. This is related to the increase at that time in the borrowings of the parent company from the Bank.

Zaibatsu members accounted for less than $1 \%$ of the deposits of the Bank during the Gōshi period, and probably only 2-3\% during the subsequent period. This contrasts sharply with the Mitsui zaibatsu, where we have data on the deposits of the parent company, Mitsui Gōmei Kaisha, and the four principal member firms, Mitsui Bussan Co. ("Mitsui Trading"), Mitsui Mining Co., Mitsui Trust Co. and Mitsui Life Insurance Co. During our first period (1921-1936), the deposits of these five firms alone accounted for 5-12\% of Mitsui Bank's deposits, and averaged 6-7\% from 1937 on. Details are not available, but the greatest share was probably from Mitsui Bussan, as changes in its deposits change the share of all member firm deposits. Deposits by Mitsui Gōmei with its bank were also much larger than those of the Sumitomo parent company with its bank, although in terms of the share of Mitsui Bank deposits, those of the parent firm were still relatively small. In addition, after the establishment of Mitsui Trust in 1924, Mitsui Mining maintained most of its deposits there rather than with Mitsui Bank. The main difference between the two zaibatsu therefore seems to be the presence of Mitsui Bussan, although there were also considerable amounts of the deposits of Mitsui Gōmei and for a time Mitsui Mining. Within the Sumitomo zaibatsu there was no single depositor of the scale of Mitsui Bussan, and in addition the parent firm absorbed much of the excess funds of member firms, more than Sumitomo Bank. The net outcome was the low dependence of Sumitomo Bank on zaibatsu. 
Table 4 Related Firm Deposits, Sumitomo \& Mitsui Banks

(unit 1,000 yen/\%)

Deposits with
Sumitomo

Goshi

Deposits with Sumitomo Bank from:

$\begin{array}{cccc}\text { Sumitomo } & \text { Member } & \text { Special } & (A)+(B)+(C) / \\ \text { Goshi (A) } & \text { Firms (B) Deposits (C) Total Deposits }\end{array}$

\begin{tabular}{|c|c|c|c|c|c|}
\hline 1923 & $?$ & $?$ & $?$ & $?$ & \\
\hline 1924 & 5,616 & $?$ & $?$ & & \\
\hline 1925 & 7,941 & $?$ & 3,222 & & \\
\hline 1926 & 8,483 & 211 & 3,179 & & \\
\hline 1927 & 10,253 & $?$ & 2,914 & & \\
\hline 1928 & 11,888 & $?$ & 3,370 & 612 & (0.6) \\
\hline 1929 & 12,615 & 398 & 2,197 & 600 & 0.5 \\
\hline 1930 & 17,536 & 106 & 1,367 & 1,693 & 0.5 \\
\hline نं 1931 & 14,432 & 33 & 737 & 3,393 & 0.6 \\
\hline 1932 & 13,276 & 50 & 1,961 & 4,103 & 0.8 \\
\hline 1933 & 12,722 & 203 & 3,314 & 4,639 & 1.0 \\
\hline 1934 & $?$ & $?$ & $?$ & 5,932 & \\
\hline 1935 & $?$ & 18,264 & $?$ & 6,788 & (2.6) \\
\hline 1936 & 13,338 & 1,695 & $?$ & 7,809 & (0.9) \\
\hline 1937 & 11,891 & 961 & 17,673 & 850 & 1.7 \\
\hline 1938 & 12,113 & 6,131 & 16,808 & 5,550 & 2.0 \\
\hline 1939 & 19,007 & 3,749 & 39,384 & 2,800 & 2.3 \\
\hline 1940 & 7,611 & 16,366 & 42,030 & 15,500 & 3.0 \\
\hline 1941 & 7,128 & 21,730 & 54,610 & 20,600 & 3.2 \\
\hline 1942 & $?$ & 20,614 & 69,777 & $?$ & \\
\hline 1943 & $?$ & 16,173 & 121,659 & $?$ & \\
\hline
\end{tabular}

C(2). Changes in Loans

Loans from Sumitomo Bank to the members of the zaibatsu are given in Table V, again along with some comparable data for the Mitsui zaibatsu. Unfortunately during the Goshi period there is not much information available until about 1929, but in general the share of loans to members of the zaibatsu in the total portfolio of the Bank must have been minimal until the 1930's, reflecting the minimal dependence of zaibatsu members on loans in general. Even for the first few years after 1929, when data is available, the amount of such loans was small, on the order of $¥ 7-8$ 
(unit 1,000 yen/\%)

Deposits with Mitsui Bank From:

\begin{tabular}{|c|c|c|c|c|c|}
\hline $\begin{array}{l}\text { Five Mitsui } \\
\text { Firms (D) }\end{array}$ & $\begin{array}{l}\text { (D)/ Total } \\
\text { Deposits }\end{array}$ & $\begin{array}{l}\text { Mitsui } \\
\text { Gomei (E) }\end{array}$ & $\begin{array}{l}\text { Mitsui } \\
\text { Mining (F) }\end{array}$ & $\begin{array}{l}\text { Mitsui Bussan } \\
(D)-(E+F)\end{array}$ & $\begin{array}{l}\text { Mitsui Trust } \\
\text { Mitsui Life } \\
\text { Insurance }\end{array}$ \\
\hline 37,960 & 9.1 & 8,383 & 14,769 & 14,808 & \\
\hline 32,370 & 7.9 & 9,241 & 10,478 & 12,651 & \\
\hline 49,690 & 11.3 & 7,954 & 8,624 & 33,112 & \\
\hline 55,340 & 12.1 & 6,518 & 7,042 & 41,780 & \\
\hline 69,450 & 12.4 & 11,613 & 4,671 & 53,166 & \\
\hline 72,450 & 12.0 & 12,864 & 3,166 & 56,420 & \\
\hline 66,310 & 10.0 & 14,031 & 916 & 51,363 & \\
\hline 48,290 & 7.2 & 12,393 & 0 & 35,897 & \\
\hline 63,180 & 9.9 & 14,102 & 0 & 49,078 & \\
\hline 35,880 & 5.2 & 14,785 & 0 & 21,095 & \\
\hline 58,970 & 8.2 & 34,499 & 0 & 24,471 & \\
\hline 54,490 & 7.3 & 22,667 & 0 & 31,823 & \\
\hline$?$ & & 28,680 & 0 & & \\
\hline$?$ & & 47,169 & & & \\
\hline$?$ & & 17,027 & & & \\
\hline 80,022 & 7.1 & 4,822 & 15,435 & 50,522 & 9,243 \\
\hline 81,220 & 6.0 & 11,466 & 5,351 & 56,112 & 8,291 \\
\hline 93,223 & 5.9 & 1,929 & 7,982 & 65,667 & 17,645 \\
\hline \multicolumn{6}{|l|}{$?$} \\
\hline \multicolumn{6}{|l|}{$?$} \\
\hline$?$ & & & & & \\
\hline
\end{tabular}

Notes: For sources see Rider (2) (4). ( ) indicates author's estimates. Total Mitsui Bank deposits, and Trust/Life deposits, are as of Dec. 31st, Mining deposits are as of Nov. 30th, and Parent deposits as of Jan 31st. Bussan deposits are the residual of total deposits less these other deposits.

million, and at the peak $¥ 14$ million. Loans to the parent firm, Sumitomo Gōshi, were greatest at the time of its establishment in 1923, and declined rapidly thereafter; the parent firm was a net depositor with the Bank by 1925 , and probably continued to be so through the early 1930's. Borrowing from the Bank increased some after 1930, but these loans were all repaid at the time of the sale of stockholdings in Sumitomo Metal Industries in 1935. Loans by the parent firm to other members of the zaibatsu were a few million yen every year during this period. During the Honsha period loans by the Bank to members of the zaibatsu increased 
rapidly, while loans by the parent firm became relatively less important.

During the Gōshi period loans to member firms had come to at most $5 \%$ of the Bank's portfolio. During the Honsha period however the share of such loans had reached $17 \%$, going from a figure that was surprisingly small to one tht was surprisingly large, and that had increased at a rapid pace. The share of Mitsui Bank's loans to the five largest members of its zaibatsu ranged from a few percent to $17 \%$ prior to 1937 , but this does not seem to have changed much thereafter. By the end of the Honsha period then Sumitomo Bank was much more dependent on members of its zaibatsu than Mitsui Bank on its related companies, a reversal of the situation in the 1920's and early 1930's. Again it should be pointed out that the impact of Mitsui Bussan was very important in this. Of the five main firms, Mitsui Bank had no loans to Mitsui Trust or Mitsui Life, while loans to the parent company and to Mitsui Mining decreased slowly from around 1925 until 1930. The bulk of the loans therefore were to Mitsui Bussan. In the late 1930's Mitsui Bussan loan demand declined, and hence Mitsui Bank loans to related companies as a whole declined, while the boom in manufacturing affected the loan demand of the core companies of the Sumitomo zaibatsu.

Finally, there is some evidence on the policy of Sumitomo Bank on loans to related firms. In the Eighty-Year History of Sumitomo Bank it is stated that "a ceiling was set on total loans by the Bank to related firms (including the parent company), and this was strictly observed." For the ceiling itself, it goes on to comment that "it appears that at first the limit was set at $10 \%$ of fixed deposits and then revised to $10 \%$ of total deposits," and that "within this overall ceiling there was a limit set for each firm on unsecured credit; anything over that limit had to have collateral. These limits were set as part of the annual business guidelines towards member firms." 4) But as can be seen in Table 5, loans stayed well beneath this ceiling before 1937, after which they rapidly approached it, and in 1943 surpassed it.

\section{Growth of Own Capital}

To carry the analysis one step further, the patterns of growth of assets and the sectoral sources of these investment funds will be traced. Here the focus will be on own capital, which consists of (1) paid-up capital, (2) various reserve funds and carried-over accounts, and (3) current-period profits. In a strict sense, current profits should not include director's bonuses and dividends paid as payments to outside the firm, but it was not possible to make this correction here. Next, the analysis will be made by contrasting two points in time, 1932 and 1940. By the year 1932 Sumi- 
Table 5 Loans to Related Firms, Sumitomo \& Mitsui Banks

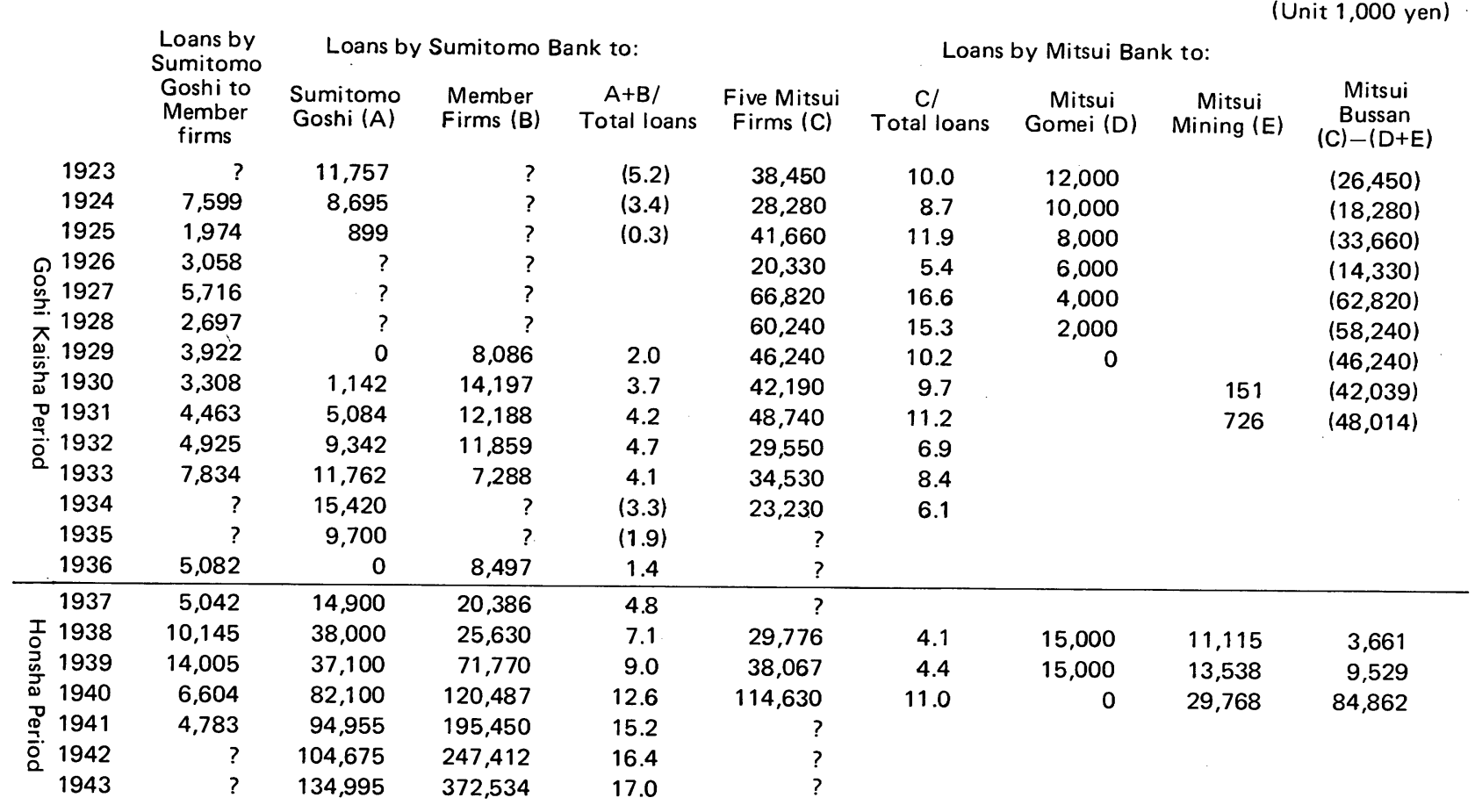

¿ Note: See Rider (2) (4) etc. for sources. 
tomo had finished the bulk of its diversification, which left it a broadranged zaibatsu; it was also a year of recession. In contrast 1940 was a boom year, centered on the war-related manufacturing sectors. Table 6 presents the basic data, and to make comparison easier includes at least own capital for zaibatsu members, including the parent firm and financial institutions. For non-financial firms and the parent company summary balance sheet data is given, as well as total assets to give an indication of the relative size of these firms.

For 1932 the first observation is that paid-up capital, a principal component of own capital, was greater for services than for the other two sector, mining and manufacturing. This is due primarily to Osaka North Harbour, with a paid-up captial of $¥ 35$ million and Sumitomo Warehouse with a paid-up capital of $¥ 15$ million. Both enterprises were extremely large from the start, and with their need for extensive land holdings and buildings this is hardly surprising. In contrast to this the four major manufacturing firms and the two mining firms had relatively little paid-up capital, perhaps because under the impact of depreciation the book value of fixed investment was small. The manufacturing sector though had substantial retained earnings, while those of the service sector were minimal and the mining sector even showed a cumulative net loss. The financial sector had both a large amount of paid-up capital and of retained earnings, and overall showed the greatest profitability of any part of the zaibatsu. This was primarily because of Sumitomo Bank, and the Sumitomo Trust, given its short history, had surprisingly large retained earnings. Finally, in terms of own capital of total assets only two firms stand out, the parent firm, Sumitomo Gōshi, and Sumitomo Bank.

In 1940 the situation is very different. Except for electric power, the service sector has barely advanced, and its weight within the zaibatsu as a whole has therefore declined substantially. Of the four service sector companies, only Shikoku Central Electric Power Co., under the impetus of the growth of the Sumitomo manufacturing enterprises located in its district, had increased its capitalization. The paid-up capital of the other three, Sumitomo Warehouse, Osaka North Harbour and Sumitomo Building, was the same as at the time of their founding, and they had only a modest amount of retained earnings. In the mining sector Sumitomo Besshi Mine and Sumitomo Colliery had merged, and production and hence own capital of the new Sumitomo Mining had surpassed the total of that of its predecessors.

In the manufacturing sector Sumitomo Chemical, Sumitomo Electric Industries, and Sumitomo Metal Industries showed tremendous growth; 
Table 6 Summary Balance Sheets, $1932 \& 1940$

\begin{tabular}{|c|c|c|c|c|c|c|c|c|c|}
\hline & 1932 & $\begin{array}{l}\text { Sumitomo } \\
\text { Steel Tube } \\
\text { \& Copper } \\
\text { Works }\end{array}$ & $\begin{array}{l}\text { Sumitomo } \\
\text { Steel } \\
\text { Works }\end{array}$ & $\begin{array}{l}\text { Sumitomo } \\
\text { Electric } \\
\text { Wire \& } \\
\text { Cable Works }\end{array}$ & $\begin{array}{c}\text { Sumitomo } \\
\text { Fertilizer } \\
\text { Works }\end{array}$ & $\begin{array}{l}\text { Sumitomo } \\
\text { Warehouse }\end{array}$ & $\begin{array}{l}\text { Osaka } \\
\text { North } \\
\text { Harbour }\end{array}$ & $\begin{array}{l}\text { Tosa Yoshi- } \\
\text { Nogawa } \\
\text { Hydro Ele- } \\
\text { ctric Power }\end{array}$ & $\begin{array}{c}\text { Sumitomo } \\
\text { Building }\end{array}$ \\
\hline $\begin{array}{l}\text { Assets } \\
\text { (A) }\end{array}$ & $\begin{array}{l}\text { Fixed Assets } \\
\text { Investment } \\
\text { Securities } \\
\text { Liquid Assets } \\
\text { Cash \& Deposit }\end{array}$ & $\begin{array}{r}9,343 \\
16 \\
1,511 \\
6,327 \\
2,312\end{array}$ & $\begin{array}{r}5,793 \\
152 \\
129 \\
2,610 \\
4,486\end{array}$ & $\begin{array}{r}5,364 \\
49 \\
3,762 \\
6,376 \\
4,392\end{array}$ & $\begin{array}{r}7,202 \\
3,218 \\
100 \\
1,891\end{array}$ & $\begin{array}{r}17,586 \\
2,310 \\
3,156 \\
64\end{array}$ & $\begin{array}{r}36,170 \\
16 \\
2 \\
6 \\
596\end{array}$ & $\begin{array}{r}6,522 \\
138 \\
83 \\
1\end{array}$ & 10574 \\
\hline $\begin{array}{c}\text { Capital } \\
\text { (B) }\end{array}$ & $\begin{array}{l}\text { Paid-in Capital } \\
\text { Reserve Funds } \\
\text { Current Profits } \\
\text { Sub Total }\end{array}$ & $\begin{array}{r}12,000 \\
2,541 \\
962 \\
15,503\end{array}$ & $\begin{array}{r}9,000 \\
1,778 \\
403 \\
11,181\end{array}$ & $\begin{array}{r}12,500 \\
4,388 \\
572 \\
17,460\end{array}$ & $\begin{array}{r}5,800 \\
713 \\
113 \\
6,626\end{array}$ & $\begin{array}{r}15,000 \\
1,342 \\
188 \\
16,530\end{array}$ & $\begin{array}{r}35,000 \\
1,020 \\
113 \\
36,133\end{array}$ & $\begin{array}{r}3,000 \\
292 \\
94 \\
3,386\end{array}$ & $\begin{array}{r}6,500 \\
455 \\
227 \\
7,182\end{array}$ \\
\hline $\begin{array}{l}\text { Liabilities } \\
\text { (C) }\end{array}$ & $\begin{array}{l}\text { Loans } \\
\text { Discount } \\
\text { Notes Payable } \\
\text { Current Liabilities }\end{array}$ & 4,008 & 1,992 & 2,486 & $\begin{array}{r}2,700 \\
941\end{array}$ & 6,032 & 504 & 3,260 & 3,402 \\
\hline$A=B+C$ & Total & 19,514 & 13,175 & 19,947 & 12,414 & 23,118 & 36,794 & 6,743 & 10,595 \\
\hline
\end{tabular}


ㅇ (continued)

1932

\begin{tabular}{|c|c|}
\hline $\begin{array}{r}\text { Assets } \\
\text { (A) }\end{array}$ & $\begin{array}{l}\text { Fixed Assets } \\
\text { Investment } \\
\text { Securities } \\
\text { Liquid Assets } \\
\text { Cash \& Deposit }\end{array}$ \\
\hline $\begin{array}{c}\text { Capital } \\
\text { (B) }\end{array}$ & $\begin{array}{l}\text { Paid-in Capital } \\
\text { Reserve Funds } \\
\text { Current Profits } \\
\text { Sub Total }\end{array}$ \\
\hline $\begin{array}{l}\text { Liabilities } \\
\text { (C) }\end{array}$ & $\begin{array}{l}\text { Loans } \\
\text { Discount } \\
\text { Notes Payable } \\
\text { Current Liabilities }\end{array}$ \\
\hline$A=B+C$ & Total \\
\hline & 1940 \\
\hline
\end{tabular}

\begin{tabular}{|c|c|}
\hline Assets & $\begin{array}{l}\text { Fixed Assets } \\
\text { Investment } \\
\text { Securities } \\
\text { Liquid Assets } \\
\text { Cash \& Deposit }\end{array}$ \\
\hline Capital & $\begin{array}{l}\text { Paid-in Capital } \\
\text { Reserve Funds } \\
\text { Current Profits } \\
\text { Sub Total }\end{array}$ \\
\hline Liabilities & $\begin{array}{l}\text { Loans } \\
\text { Notes Payable } \\
\text { Bond } \\
\text { Current Liabilities }\end{array}$ \\
\hline
\end{tabular}

\begin{tabular}{|c|c|c|c|}
\hline $\begin{array}{c}\text { Sumitomo } \\
\text { Besshi } \\
\text { Mine }\end{array}$ & $\begin{array}{c}\text { Sumitomo } \\
\text { Colliery }\end{array}$ & $\begin{array}{c}\text { Sumitomo } \\
\text { Bank }\end{array}$ & $\begin{array}{c}\text { Sumitomo } \\
\text { Trust }\end{array}$ \\
\hline
\end{tabular}

$$
\begin{array}{r}
13,255 \\
1,070 \\
594
\end{array}
$$

13,760

11,015

498

15,000

$-593$

$-107$

14,300

2,450

9,687
26,439

26,439

Sumitom
Metal

Industries

69,175

66,061

70,237

220,309

25,918

150,000

148,298

13,410

311,708

68,100

20,000

51,895

451,705
90

100

2,194

764
76

12,000

$-1,706$

$-476$

9,818

5,563

844

16,227

Sumitomo

Electric

Industries

12,915

7,395

29,172

46,782

5,213

45,000

21,918

3,565

70,483

20,985

10,012

101,484

50,000
27,397
3,887
81,284

5,000
3,692
419

419
9,111

750
415
536

1,701

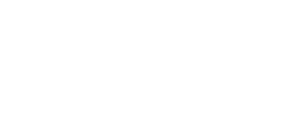

Sumitomo Manchuria

Sumitomo Sumitomo Aluminium Sumitomo
Chemical Machinery
Reduction Steel Tube

35,427

14,078

13,759

22,182

2,649

40,000

12,273

2,204

54,477

9,000

4,726

4,726
191

12,911

7,047

172

8,878

15,137

6,679

679
92

15,000

2,970

1,232

19,202

10,000

648

354

11,002

13,920

23,385

10,802

13,720

377

20,000

1,031

996

22,027

21,973

20,000

4,618

13,444

32,649

1,980

4,285

26.906

48,288
Sumitomo

Goshi

Kaisha

(Head Office)

10,696

$$
1,740
$$

161,902

17,651

4.103

150,000

11,898

$-287$

161,611

3,240

12,968

18,272

196,094

Sumitomo

Warehouse

15,103

86
1,726

3,155

15,000

3,291

740

19,031

1,417
Osaka

North

Harbour

25,530

2,457

4,569

5,077

35,000

2,500

447

37,947

384

38,334 


\begin{tabular}{|c|c|c|c|c|c|c|c|c|}
\hline & 1940 & $\begin{array}{l}\text { Shikoku } \\
\text { Central } \\
\text { Electric } \\
\text { Power }\end{array}$ & $\begin{array}{c}\text { Sumitomo } \\
\text { Building }\end{array}$ & $\begin{array}{l}\text { Sumitomo } \\
\text { Mining }\end{array}$ & $\begin{array}{c}\text { Sumitomo } \\
\text { Bank }\end{array}$ & $\begin{array}{c}\text { Sumitomo } \\
\text { Trust }\end{array}$ & $\begin{array}{c}\text { Sumitomo } \\
\text { Life } \\
\text { Insurance }\end{array}$ & $\begin{array}{c}\text { Sumitomo } \\
\text { Honsha } \\
\text { (Head } \\
\text { Office) }\end{array}$ \\
\hline Assets & $\begin{array}{l}\text { Fixed Assets } \\
\text { Investment } \\
\text { Securities } \\
\text { Liquid Assets } \\
\text { Cash \& Deposit }\end{array}$ & $\begin{array}{r}31,789 \\
1,509 \\
5,688 \\
18\end{array}$ & $\begin{array}{r}10,291 \\
479\end{array}$ & $\begin{array}{r}27,954 \\
19,755 \\
17,726 \\
36,085 \\
1,539\end{array}$ & & & & $\begin{array}{r}4,436 \\
271 \\
200,739 \\
106,894 \\
22,400\end{array}$ \\
\hline Capital & $\begin{array}{l}\text { Paid-in Capital } \\
\text { Reserve Funds } \\
\text { Current Profits } \\
\text { Sub Total }\end{array}$ & $\begin{array}{r}17,500 \\
827 \\
760 \\
19,087\end{array}$ & $\begin{array}{r}6,500 \\
1,838 \\
303 \\
8,641\end{array}$ & $\begin{array}{r}27,000 \\
9,642 \\
1,190 \\
37,832\end{array}$ & $\begin{array}{r}50,000 \\
53,540 \\
6,109 \\
109,649\end{array}$ & $\begin{array}{r}5,000 \\
10,529 \\
985 \\
16,514\end{array}$ & $\begin{array}{r}750 \\
972 \\
594 \\
2,316\end{array}$ & $\begin{array}{r}150,000 \\
13,963 \\
1,245 \\
165,208\end{array}$ \\
\hline \multirow[t]{3}{*}{ Liabilities } & \multirow{3}{*}{$\begin{array}{l}\text { Loans } \\
\text { Notes Payable } \\
\text { Bond } \\
\text { Current Liabilities }\end{array}$} & 8,400 & 2,940 & $\begin{array}{l}12,730 \\
30,675\end{array}$ & & & \multirow[t]{3}{*}{ Discount } & 148,600 \\
\hline & & $\begin{array}{r}10,000 \\
1,259\end{array}$ & 28 & 21,824 & & & & 20,933 \\
\hline & & 38,752 & 11,611 & 103,064 & & & & 334,741 \\
\hline
\end{tabular}

Notes: See Rider (4) etc. for sources. 
they and their subsidiaries had become the predominant firms within the zaibatsu. Sumitomo Metal, by far the largest of these, was in terms of own capital three times the size of Sumitomo Bank and twice that of Sumitomo Honsha, the parent company; retained earnings were about as great as its paid-up capital of $¥ 150$ million. The paid-up capital of the parent company itself had remained at $¥ 150$ million, unchanged since its founding in 1922, in spite of the 1937 reorganization from Gōshi to Honsha. While some accumulated profits were disposed of at the time of the reorganization, the 1940 retained earnings were small, at $¥ 14$ million. The growth in total assets also reflects the impact of the war, as military orders led. to an increase in manufacturing output, and hence of inter-firm credit and inventories.

Finally, let me summarize the structure of the accumulation of profits. As has been indicated above, the profits to which the member firms gave rise each year were absorbed as dividends by the parent firm. The profits thus pooled would then be used to increase the capitalization of member firms, in the form of additional investment in them by the parent firm. Any amount remaining after the payment of dividends by the individual member firms would then be used to build up these companies' reserves. As shareholdings by zaibatsu outsiders were extremely limited, the profits of zaibatsu members would thus show up as increases in own capital of zaibatsu members through one of these two routes. This did not take place for each individual firm, but rather the "excess" funds of highly profitable companies such as Sumitomo Bank and Sumitomo Electric Wire \& Cable would flow to other zaibatsu members via the parent firm. The growth of own capital of the zaibatsu thus took place in the member firms, and not in the parent. During the Sumitomo Honsha period less data is available and so it is harder to trace out the flow of funds, but it seems that the structure remains the same. During this period though the profits of the manufacturing sector became sufficiently great that the flow of funds from the other sectors of the zaibatsu was less important.

\section{Concluding Comments}

In the preceeding part of the paper the flow of funds of the Sumitomo zaibatsu was detailed, and it would be repetitious to present those results again. Here some further observations of a more general character will be made.

The first is the relation between the composition of a zaibatsu and the structure of its supply of and demand for funds. In general, the flow of funds within a zaibatsu, and the methods of fund-raising of mem- 


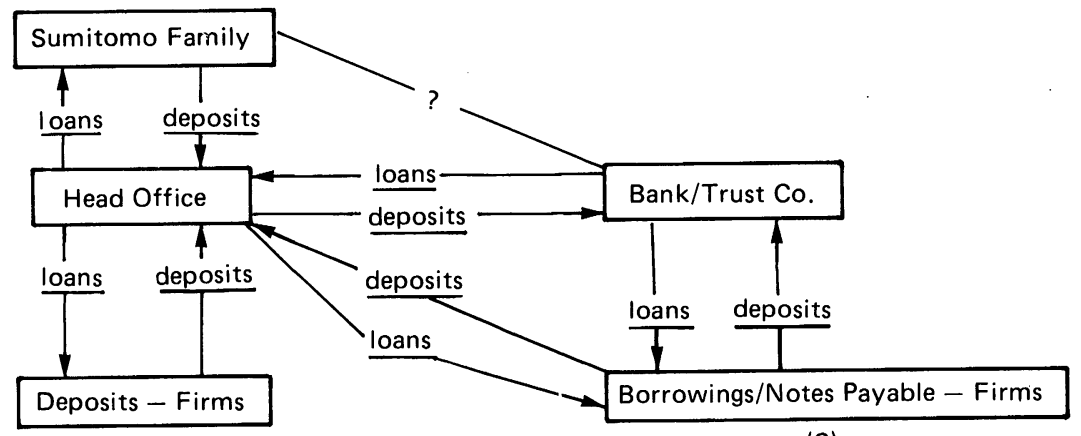

(1)

(2)

(1) Osaka North Harbour

Sumitomo Steel Works

Sumitomo Electric Wire \& Cable Works

Sumitomo Machinery

Manchuria Sumitomo Steel \& Tube

Sumitomo Besshi Mine

(2) Sumitomo Warehouse

Tosa Yoshinogawa Hydroelectric Power

Sumitomo Building

Sumitomo Fertilizer Works

Sumitomo Colliery

Sumitomo Steel Tube \& Copper Works

ber firms, can be expected to be related to the sort of firms within it, and to the nature of their links with each other. For example, within Sumitomo at this time there was no trading firm comparable in scale to Mitsui Bussan, the mining sector was both smaller and less profitable than that of Mitsui and there was only one giant firm, Sumitomo Bank, in contrast to three giant firms in the Mitsui zaibatsu, Mitsui Bank, Mitsui Bussan and Mitsui Mining. The pattern of the flow of funds thus differed. The flow of funds within the Sumitomo zaibatsu during the Goshi period (1921-1936) is summarized in Figure 1. Here the parent firm supervised the distribution of funds within the group. Within Mitsui there were large changes in the demand for short-term funds due to swings in the activities of Mitsui Bussan, but there were no such swings in short-term fund demand within Sumitomo. The demand for funds could thus largely be self-financed by the Sumitomo zaibatsu. This changed during the 
Figure 2 The Funding Structure during the Sumitomo Honsha Period

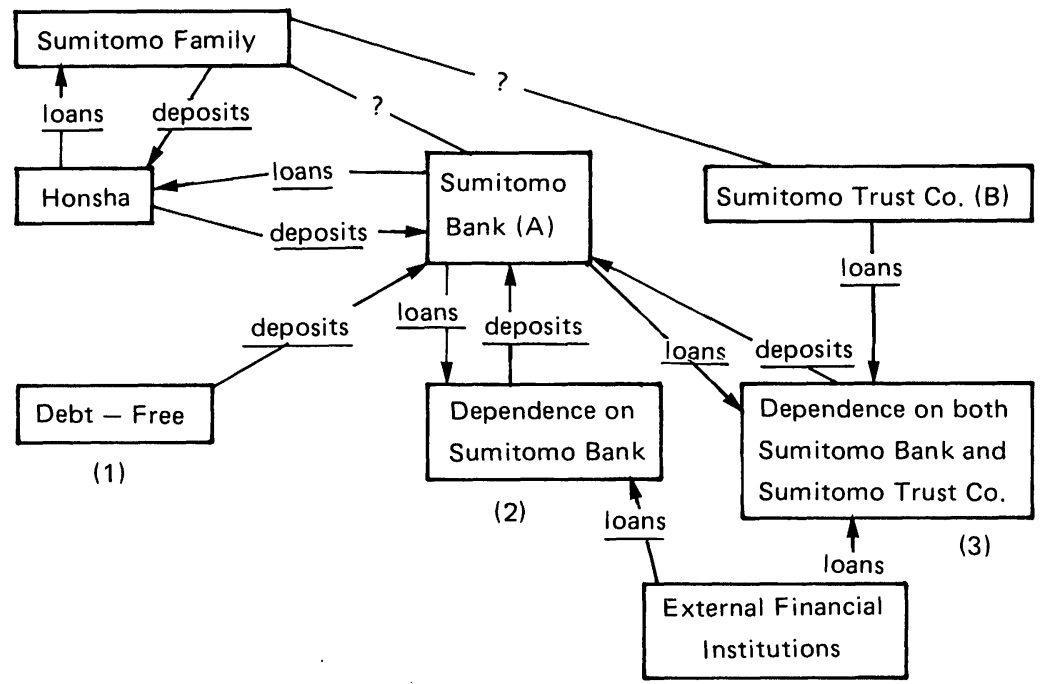

(1) Osaka North Harbour

Sumitomo Warehouse

(2) Sumitomo Aluminium Reduction

Sumitomo Electric Industries

Sumitomo Metal Industries

Manchuria Sumitomo Metal Industries

Sumitomo Machinery

(3) Sumitomo Mining

Sumitomo Chemical

Shikoku Central Electric Power

Nippon Electric

war period, when with the growth of the manufacturing sector of the Sumitomo zaibatsu the demand for funds surpassed its internal financing capacity. Members of the Sumitomo zaibatsu thus had to resort to external financing, including loans, bonds and public stock flotations. The new flow of funds pattern is summarized in Figure 2. It should be noted that the heavy and chemical industries had not been as important in the Mitsui zaibatsu, and so it did not depend as much on external financing under the impact of the war as did the Sumitomo zaibatsu.

Second, the role of the parent companies was different in the various 
zaibatsu. While their status as holding companies has been widely discussed, their role in the internal financing of the various zaibatsu has been little studied. In the case of Sumitomo, the parent firm functioned as a financial intermediary for the members of the zaibatsu, although it did not meet all their financing needs. Sumitomo Bank stayed in the background, meeting the occasional needs of the parent firm, at least until the onset of the war. The parent firm took up the excess funds of the zaibatsu members, rather than permitting them to freely dispose of their cash, but as the need arose it would return this money or even loan additional funds. In this way the flow of funds between different sectors of the zaibatsu could be controlled. In addition, during the Gōshi period, many of the large establishments within the zaibatsu were run as operating divisions of the parent firm; financial flows among them were handled internal to Sumitomo Gōshi. When these operations were spun off into separate companies, the parent firm continued in its role of financial coordinater; in many ways they were thus independent firms in name only.

It is not yet possible to say whether the Sumitomo zaibatsu was unique in the role that its parent firm played. That of the parent firm of the Mitsubishi zaibatsu, the Mitsubishi Gōshi Kaisha, seems to have been similar until 1929. ${ }^{5}$ ) The role of the parent company within the Mitsui zaibatsu has not been well delineated, but from the mid-1920's on it is said that it was Mitsui Bussan instead of the parent firm which used its excess funds to intermediate in the financing of the zaibatsu. ${ }^{6}$ ) With the current state of knowledge it is not however possible to make any precise comparisons of the role played by these three firms.

Finally, the role of the financial institutions within the zaibatsu, and especially that of the banks, should reflect differences in the sectoral structure of the various zaibatsu. For Sumitomo, the Bank was connected in three ways to other firms. The first was of course its making loans to member firms, but it also had a second intermediary role in meeting the funding needs of the parent firm, which then funded other firms. Its third tie was in the payment of its profits out as dividends to the parent firm, which in turn reinvested them in other members of the zaibatsu. The first two show up as loans from the Bank, and as noted in the main part of the paper, loans to related firms were only a small part of Sumitomo Bank's portfolio; deposits by zaibatsu members were also relatively minor. The small role of the Bank reflects the ability of the Sumitomo zaibatsu over most of its life to finance itself.

Within the Mitsui zaibatsu, the role of Mitsui Bank was fundamentally the same, but for the presence of two firms. Mitsui Bussan had a tre- 
mendous demand for funds, and this was reflected in the proportion of the total loans of Mitsui Bank to members of its zaibatsu. Mitsui Bussan and Mitsui Mining were also large depositors, and this likewise was reflected in the share of total deposits which came from related firms. Within Sumitomo there were no firms which stood out in this way. But as mentioned previously, with its relatively greater concentration in manufacturing, the Sumitomo zaibatsu grew much faster than Mitsui during the war, and this eventually resulted in a greater share of loans to related firms by Sumitomo Bank than by Mitsui Bank.

\section{Notes}

1) Adapted from "Sumitomo Zaibatsu ni okeru Shikin Chotatsu no Seikaku", Keiei Shigaku (Japan Business History Review), Vol. 16 No. 2 (July 1981).

2) Member firms were those owned by, and with management controlled by, the parent firm. Affiliated firms were those with strong ties with, but not fully controlled by, the parent firm.

3) Shoichi Asajima, "Ryotaisen-kan ni okeru Sumitomo Zaibatsu no Shushi Kozo" ("The Financial Structure of the Sumitomo Zaibatsu in the Inter-war Period"), Shakai Kagaku Nenpo (Senshu University) 15, (March 1981).

4) Sumitomo Ginko Hachiju-Nen Shi (80 Year History of Sumitomo Bank), pg. 361. In terms of overall loan allocation, the History goes on to state that "there was no formal rule or restriction, and it appears that it was an item decided upon jointly by the chief officers of the Bank and the parent company. There is nothing though to indicate in what manner such consultation took place."

5) For Mitsubishi the "Bunkei Kaisha to Gōshi Kaisha tono Kankei Torikime" ("Agreement on Relations Between Mitsubishi Gōshi Kaisha and its Related Firms") of January 14, 1918 sets forth that "the finances of each firm are to be handled for now through the parent company, Mitsubishi Gōshi Kaisha", and then details how this was to be done. This agreement was abolished in June 1929, but it is likely that the parent firm continued to handle the finances of its related firms until then. The original sources are the Documents of Mitsubishi Company (Mitsubishi Gōshi Kaisha Shashi) and the Documents of Mitsubishi Limited (Mitsubishi Shashi).

6) See Hiroshi Matsumoto, "Zaibatsu Shihon no Chikuseki Kozo" (The Structure of Capital Accumulation of the Zaibatsu), in The Great Depression, Vol. I of The Society and Nation under Fascism 
edited by University of Tokyo Social Science Research Center (Tokyo Daigaku Shakai Kagaku Kenkyujo Hen, Fashizumu Ki no Kokka to Shakai, Dai-ichi Kan, Showa Kyoko )., pp. 65-66.

\section{List of Statistical Sources}

1) Yoshio Asai, "1920 Nendai ni okeru Mitsui Ginko to Mitsui Zaibatsu" (Mitsui Bank and the Mitsui Zaibatsu in the 1920's), Mitsui Bunko Ronso (The Journal of Mitsui Research Institute for Social and Economic History), 11 (1977).

2) "Mitsui Kakusha oyobi Kankei Kaisha Yotai Kinbetsu Shirabe". (Report on Loans and Deposits of Mitsui Zaibatsu Members and Affiliates), Mitsui Ginko Shiryo 5 (Historycal Records of the Mitsui Bank), (1978).

3) Sumitomo Ginko 80-Nen Shi, Sumitomo Ginko Hen, 1979. (EightyYear History of Sumitomo Bank).

4) Sumitomo Jissai Hokoku Sho, 1920-1941. (Annual Report to Directors). 